\title{
Surveying in-service preschool teachers' technological pedagogical content knowledge
}

\author{
Jyh-Chong Liang \\ National Taiwan University of Science and Technology, Taiwan \\ Ching Sing Chai, Joyce Hwee Ling Koh \\ Nanyang Technological University, Singapore \\ Ching-Ju Yang \\ National Taichung University of Science and Technology, Taiwan \\ Chin-Chung Tsai \\ National Taiwan University of Science and Technology, Taiwan
}

\begin{abstract}
Many teachers are reporting that they need to develop more subject-specific applications of educational technology. However, there seems to have been a lack of theoretical frameworks to guide educators in preparing and developing in-service preschool teacher education in the area of educational technology until the recent emergence of the notion of technological pedagogical content knowledge (TPACK). This study utilizes the TPACK survey to explore 366 Taiwanese in-service preschool teachers' technological pedagogical content knowledge. Exploratory factor analyses of the TPACK survey used in this study yielded six scales: Content knowledge (CK), pedagogical knowledge (PK), pedagogical content knowledge (PCK), technological knowledge (TK), a combined factor of technological pedagogical knowledge and technological content knowledge (TPTCK) and technological pedagogical content knowledge (TPCK), respectively. The exploratory factor analyses indicated adequate reliability and validity of the TPACK survey. The correlation analyses revealed that more senior preschool teachers might show a certain degree of resistance toward technology-integrated teaching environments. Further analyses also showed that the preschool teachers with higher education qualifications tended to have more knowledge of technology use and ICT integration in their teaching environment.
\end{abstract}

\section{Introduction}

In recent years, technological pedagogical content knowledge (TPACK) has emerged as a promising theoretical framework for helping teachers and teacher educators to make sense of the knowledge needed for technology integration in the classroom (Mishra \& Koehler, 2006). The framework has attracted burgeoning attention among education technologists, and hundreds of publications have resulted (Graham, 2011). However, a recent review by Chai, Koh, and Tsai (2013) indicates that despite the many papers written on TPACK, very little has been done on the application of this framework in preschool education. The integration of educational technology in preschool settings is possibly not as essential as in elementary or high schools, probably due to the low level of teachers' ICT competence or the lack of resources and technical support in the preschool context $(\mathrm{Li}, 2006)$, which may explain why the TPACK framework has not caught preschool educators' attention. However, the role of technology in preschool settings is indispensable. Preschool children need concrete/analogical representations of content knowledge that is developmentally beyond their reach without some form of animation. Well-designed computer programs could also facilitate comprehension and various developments among preschoolers (e.g., Hsu, Tsai, \& Liang, 2011). Given this, we argue that it may be fruitful to explore preschool in-service teachers' perceived competence in the various components of TPACK, and to draw out implications of preschool teachers' professional development needs. In addition, as the TPACK framework is an emerging framework, examining it in different contexts is essential to enrich its usability and viability in guiding theory formation and empirical research. This study therefore explores preschool teachers' notions of TPACK through an adapted survey instrument. Given that not much prior research has been conducted for TPACK in the early childhood teacher development context, we began our work by exploring whether the adapted instrument could in fact yield the factor structure we were investigating. In addition, based on the factors we obtained, we investigated how teachers' demographic variables such as years of service and education qualifications influence their TPACK profile. 


\section{Literature review}

In the following sections, we first introduce and delineate the various constructs of TPACK. This is followed by a general review of the research carried out and the outcomes achieved to date. We devote one section particularly to issues associated with the quantitative measurement of TPACK, and conclude the review with a discussion of the general research of ICT in preschool or early childhood education.

\section{The TPACK framework and constructs}

The TPACK framework is an extension of Shulman's (1986) notion of pedagogical content knowledge (PCK). In his effort to articulate the knowledge needed by teachers, Shulman proposed that teachers not only need to have content knowledge (CK) and general pedagogical knowledge (PK) about the methods of teaching and classroom management, but that they also need to possess a unique form of knowledge which enables them to represent the content of the subject matter to specific groups of students. This form of knowledge, which is a synthesis of CK and PK and possibly other forms of knowledge such as the psychology of learners etc., is known as PCK.

With the emergence and proliferation of personal computers since the 1980s, it is clear now that teaching can and should be revolutionized by the ever more sophisticated information and communication technology (ICT) (Collins \& Halverson, 2010; Gao, Chee, Wang, Wong, \& Choy, 2011). However, while many education ministries all over the world have devoted a substantial amount of money to equipping schools with ICT, teachers' usage of the facilities has not quite realized the pedagogical affordances of ICT in creating prevalent constructivist-oriented student centred lessons (Lim \& Chai, 2008; Liu, 2011; $\mathrm{Wu}$, Lee, Chang, \& Liang, 2013). The lack of a coherent theoretical framework to guide the creation of new practices associated with the integration of ICT is one of the key issues that has been identified (Mishra \& Koehler, 2006).

In 2005, several researchers proposed the inclusion of the technological knowledge (TK) dimension into the PCK framework (Angeli \& Valanides, 2005; Koehler \& Mishra, 2009). The inclusion of TK transformed the original framework, and the new TPACK framework is arguably more comprehensive and powerful in explaining what should be done in today's classrooms. The inclusion of TK also gives rise to three new dimensions, namely technological pedagogical knowledge (TPK), technological content knowledge (TCK) and technological pedagogical content knowledge (TPCK). Mishra and Koehler (2006) depicted the TPACK framework with the seven dimensions diagrammatically as shown in Figure 1.

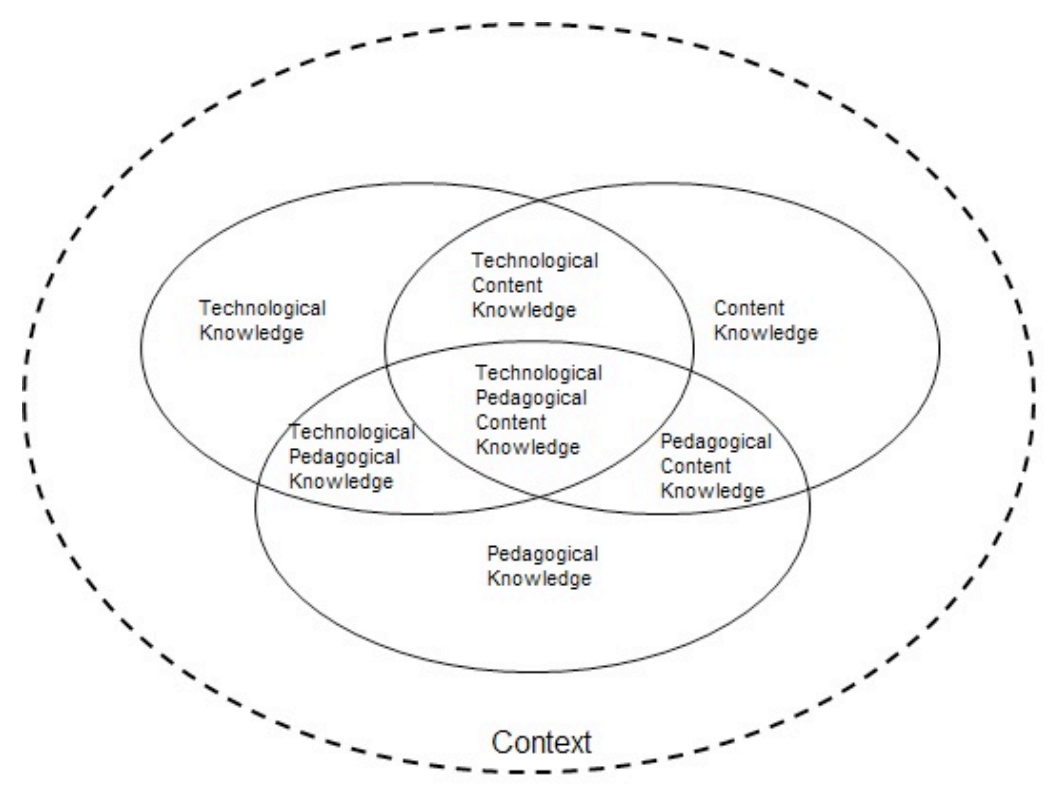

Figure 1. TPACK framework (Koehler \& Mishra, 2006; p. 63). 
The new dimensions that arise from the interaction between TK, CK, and PK obviously need clarification. Following Cox and Graham's (2009) explication of the TPACK framework, we define TCK as a representation of specific content knowledge through specific forms of technology without consideration of pedagogy. An example of TCK for preschool teachers would be clip art software such as PrintMagic built for graphic design and typesetting. Preschool teachers often use this software to edit the graphic art. These ICT-based representations were not designed primarily for teaching and learning in a preschool setting. The exclusion of pedagogical knowledge is important for establishing a clear construct for TCK. In a similar vein, TPK deals with the intersection of pedagogical knowledge and technological knowledge, and does not include references to the content that is to be taught. For example, knowledge about how online discussion forums work may be used to support young children's understanding, including one's need to set open-ended questions and set up rules of participation (Mason, 2011). This knowledge can and should be applied to any teaching of subject matter through discussion forums. Finally, the most important construct, TPCK, integrates all the other six types of knowledge. Enacted in the classroom, TPACK is a situated/contextualized form of knowledge that teachers arrive at given a specific group of learners with a unique social-historical relationship with the teachers and the subject matter (Chai, Koh, \& Tsai, 2011).

\section{General research and outcomes of the TPACK framework}

To date, the TPACK framework has prompted much fruitful research and development work. Researchers have utilized the framework to design both pre- and in-service courses for ICT integration. For example, Angeli and Valanides (2005; 2009) and Chai, Koh, and Tsai (2010) have designed ICT courses for pre-service teachers, and documented substantial gains among the pre-service teachers after they were led to consider relevant aspects of the TPACK framework.

Other than teacher professional development, the TPACK framework has also been utilized to evaluate online courses (Valtonen, Kukkonen, \& Wulff, 2006), to design software (Wu, Chen, Wang, \& Su, 2008) and to evaluate projects pertaining to pre-service teacher education on ICT (Polly, Mims, Shepherd, \& Inan, 2010). In short, the framework is versatile and may have many other potential uses. Given that, many researchers have attempted to measure the TPACK quantitatively, and their efforts are reviewed next.

\section{Surveying teachers' TPACK}

It is obvious that the TPACK framework could be used to profile teachers' perceptions or perceived competence as defined by the framework (Tee \& Lee, 2011). Survey instruments that could identify the various dimensions can be used to assess teachers' professional development needs and as a means to measure teachers' perceived growth in pre-and-post course surveys. To date, several researchers have attempted to create such an instrument for various contexts, but there seems to be only one questionnaire that has identified all seven dimensions through proper factor analyses. The earliest attempt in this direction was carried out by Schmidt et al. (2009). They attempted to measure all seven dimensions of teachers' TPACK, and their questionnaire obtained high reliability. However, due to the small sample size $(N<150)$, they only conducted exploratory factor analysis one factor at a time. The instrument could not therefore be accepted as fully validated. Koh, Chai, and Tsai (2010) attempted to validate Schmidt et al.'s questionnaire with slight adaptions for Singaporean pre-service teachers $(N>1000)$, but they obtained only five factors. While they were able to identify CK and TK as distinct factors, PK and PCK loaded as one factor, while TPK, TCK, and TPCK loaded as three other factors. The fifth factor with only two items was labelled as knowledge from a critical reflection form by two items originally from the TPK construct, and the items were associated with teachers' reflections. Archamabault and Barnett (2010) attempted to create a survey for online teachers, but the factor analysis yielded only three factors. Lee and Tsai (2010) also identified the difficulty of differentiating TPK from TPCK. The merging of factors was not surprising as Cox and Graham (2009) have pointed out that the dimensions need careful delineation. Following their suggestion, Chai, Koh, Tsai, and Tan (2011) were able to improve on Schmidt et al.'s questionnaire and they have successfully identified all seven factors. However, more work could and needs to be done in this area. 
The TPACK framework can be further contextualized to cater to the diverse contexts of teacher education. For example, the questionnaire can be contextualized as a subject specific instrument, for specific pedagogical approaches such as constructivist-oriented use of ICT or problem-based learning, and the TK items can be specifically targeted at web 2.0 instead of general TK. In this study, we validated the TPACK instrument for the context of early childhood educators, and we designed the instrument items in web-based technologies and constructivist-oriented usage of ICT.

\section{ICT usage in preschool education}

The ICT usage has been used to enhance teaching and learning in many early childhood education programs (Wang \& Hoot, 2006; Yurt \& Cevher-Kalburan, 2011). Studies have demonstrated that technology usage (i.e., the use of computers) can support children's memory development, their abilities of communication and problem-solving (Haugland, 1992), and their inherent musical skills (Panagiotakou \& Pange, 2010). It has also been found that preschool teachers usually cannot use computers in the classroom comfortably and successfully unless they have had specific training (Önkol, Zembat, \& Balat, 2011). Therefore, preschool teachers need to be trained in the use and integration of technologies in the classroom learning environment. Hence, the points of view and the practices of technology usage of preschool teachers are very important in that they could contribute significantly to the incorporation of the specific technologies used in preschool education. In the past, much previous research explored primary, secondary school or university teachers' views on or attitudes toward their usage of ICT in schools (e.g., Chai et al., 2011a; Karasavvidis, 2009; Al-Senaidi, Lin, \& Poirot, 2009); however, there are few studies regarding in-service preschool teachers' views on or intentions to integrate technologies into early childhood settings (Gialamas \& Nikolopoulou, 2010; Önkol et. al., 2011).

Some educators have expressed concerns about the utilization of technology in early childhood education (Grimley \& Allan, 2010; Linuesa, Orellana, Baz, \& Dominguez, 2011; O'Mara \& Laidlaw, 2011). These concerns include the possibility of children developing cyber addiction, eyesight problems and impediments towards social skills development. They advocate that technology should not be integrated into early childhood education. If the stance of no technology is adopted for early childhood, the enhancement of teachers' TPACK will be a non-issue. However, this paper adopts the assumption that technology has permeated all aspects of daily life and it plays an unquestionable role in children's life. While we acknowledge the possible problems technology may cause, we believe it is all the more important for preschool teachers to construct the form of TPACK needed for their unique context. Appropriate use, supported by all forms of TPACK knowledge, in order for young children to reap the pedagogical benefits of technology seems to be a better choice than avoiding technology altogether. Under such circumstances, preschool teachers may need refined understanding of proper ways of using technology for facilitating children's learning and development, thus strengthening the importance of investigating preschool teachers' TPACK.

Furthermore, one previous study (Lee \& Tsai, 2010) has found that teachers' teaching experiences and age were correlated with their TPACK while integrating web technology into their teaching practices. Lee and Tsai (2010) suggested that older teachers with more teaching experience were found to have lower TPACK self-efficacy. Additionally, there are three major groups of preschool teachers in Taiwan in terms of their educational qualifications (i.e., senior high school, junior college and university degree). Some previous studies have explored how the teachers' educational qualifications influenced their pedagogical practices (Thole, 2010) or teaching beliefs (Perry, Tracey, \& Howard, 1999). For example, Thole's study (2010) discussed the available knowledge on questions focusing on the pedagogy of early childhood staff and found that the role of higher education qualifications which is expected to promote the quality of teachers' professional commitment is still questioned. In this study, we investigated the role of different educational qualifications in preschool teachers' TPACK.

\section{Purpose}

In summary, the main purposes of this study were to develop and utilize the TPACK survey to investigate in-service preschool teachers' TPACK. The relationships between their ages, years of service and technological pedagogical content knowledge were also surveyed. This study further examined the role of in-service preschool teachers' education qualifications on their technological pedagogical content knowledge. 


\section{Method}

\section{Questionnaire}

To explore the in-service preschool teachers' technological pedagogical content knowledge, a TPACK survey was applied in this study. The survey, with 42 items, was based on Chai et al.'s (2011b) study which originally included seven scales (content knowledge (CK), pedagogical knowledge (PK), pedagogical content knowledge (PCK), technological knowledge (TK), technological pedagogical knowledge (TPK), technological content knowledge (TCK) and technological pedagogical content knowledge (TPCK)). Items from the TK factor in this research mainly focused on web-based technologies (e.g., I am able to use social media [e.g., blogs, wikis, Facebook]), while the TPK factor largely explored constructivist-oriented use of technology (e.g., I am able to facilitate my students to use technology to construct different forms of knowledge representation). The items of each scale are expressed with bipolar strongly agree/strongly disagree statements on a seven-point Likert scale, representing the teachers' perceived competence for the item statements. The details of each scale are as follows (and Table 1):

1. CK scale: evaluating in-service preschool teachers' knowledge of the subject matter.

2. PK scale: exploring in-service preschool teachers' knowledge of their instructional methods, process and assessment for teaching the intended subject matter.

3. PCK scale: assessing in-service preschool teachers' knowledge of adopting pedagogical strategies to foster learners' understanding of the subject matter.

4. TK scale: measuring in-service preschool teachers' knowledge of the capacities and applications of commonly accessible technology.

5. TPK scale: evaluating in-service preschool teachers' knowledge of using novel and specific technologies to teach or facilitate instruction.

6. TCK scale: probing in-service preschool teachers' knowledge of how the technology can be used in teaching the subject.

7. TPCK scale: assessing in-service preschool teachers' knowledge of using ICT to teach and show the designated subject content.

\section{Data collection procedure}

The participants of this study included 366 in-service preschool teachers (356 females and 10 males; average age: 35.3 years) who enrolled in the professional development courses to pursue a Bachelor's degree in Childhood Care and Education in Taiwan. These preschool teachers were divided into three academic groups based on their self-reported education qualifications (senior high school, junior college and university degree), which are also the three major groups for preschool teachers in Taiwan. The preschool teachers were invited to participate in this research on a voluntary basis, and they responded to the TPACK survey in an anonymous way. Prior to responding to the questionnaires, they were informed of the aim and importance of the study. A small token of appreciation was provided after the teachers completed the survey.

\section{Data analysis}

First, this study used exploratory factor analysis to clarify the factor structure of the TPACK survey. The alpha coefficient for each factor of the TPACK survey was calculated to ensure the reliability of each factor. Preschool teachers' descriptive data on each scale of the TPACK survey were reported. Pearson correlation analysis was undertaken to explore how the preschool teachers' age or years of service might be related to each factor of the TPACK survey. Moreover, a series of $F$-tests were further used to compare the responses of the three groups of preschool teachers, by education qualification, on each factor of the TPACK survey.

\section{Results}

\section{Factor analysis}

This study utilized exploratory factor analysis to validate the scales of the TPACK survey. The factor 
analysis presented in Table 1 shows that the preschool teachers' responses could be grouped into six scales, that is CK (4 items), PK (5 items), PCK (8 items), TK (7 items), TPTCK (a combined factor of TPK and TCK, 8 items) and TPCK (4 items). These scales accounted for $72.56 \%$ of the variance. The Eigen-values of these six scales from the principal component analysis were all larger than one, and the reliability (alpha) coefficients for the scales were $0.87-0.94$, with an overall alpha of 0.96 . Therefore, the TPACK survey with six scales in this study was considered to be adequately reliable for measuring the preschool teachers' technological pedagogical content knowledge. More importantly, the results gained in this study indicated that the TPK scale and the TCK scale merged into a single TPTCK scale.

Table 1

Rotated factor loadings and Cronbach's alpha values for the six scales of the TPACK survey for preschool teachers

\begin{tabular}{|c|c|c|}
\hline Item & Measure & $\begin{array}{c}\text { Factor } \\
\text { loading }\end{array}$ \\
\hline CK1 & I have sufficient knowledge about my teaching subject. & 0.77 \\
\hline CK2 & $\begin{array}{l}\text { I can think about the content of my teaching subject like a subject matter } \\
\text { expert. }\end{array}$ & 0.78 \\
\hline CK3 & $\begin{array}{l}\text { I am able to gain deeper understanding of the content of my teaching subject } \\
\text { on my own. }\end{array}$ & 0.64 \\
\hline CK4 & I am confident about teaching the subject matter. & 0.65 \\
\hline PK1 & I am able to guide my students to adopt appropriate learning strategies. & 0.63 \\
\hline PK2 & I am able to help my students to monitor their own learning. & 0.63 \\
\hline PK3 & I am able to help my students to reflect on their learning strategies. & 0.61 \\
\hline PK4 & I am able to plan group activities for my students. & 0.76 \\
\hline PK5 & I am able to guide my students to discuss effectively during group work. & 0.75 \\
\hline PCK1 & $\begin{array}{l}\text { Without using technology, I can address the common misconceptions my } \\
\text { students have for my teaching subject. }\end{array}$ & 0.68 \\
\hline PCK2 & $\begin{array}{l}\text { Without using technology, I know how to select effective teaching } \\
\text { approaches to guide student thinking about and learning of the subject } \\
\text { matter. }\end{array}$ & 0.76 \\
\hline PCK3 & $\begin{array}{l}\text { Without using technology, I can help my students to understand the content } \\
\text { knowledge of my teaching subject through various ways. }\end{array}$ & 0.81 \\
\hline PCK4 & $\begin{array}{l}\text { Without using technology, I can address the common learning difficulties } \\
\text { my students have with my teaching subject. }\end{array}$ & 0.82 \\
\hline PCK5 & $\begin{array}{l}\text { Without using technology, I can facilitate meaningful discussion about the } \\
\text { content students are learning in my teaching subject. }\end{array}$ & 0.85 \\
\hline PCK6 & $\begin{array}{l}\text { Without using technology, I can engage students in solving real world } \\
\text { problems related to my teaching subject. }\end{array}$ & 0.83 \\
\hline PCK7 & $\begin{array}{l}\text { Without using technology, I can engage students with hands-on activities to } \\
\text { learn the content of my teaching subject. }\end{array}$ & 0.79 \\
\hline PCK8 & $\begin{array}{l}\text { Without using technology, I can support students to manage their learning of } \\
\text { content for my teaching subject. }\end{array}$ & 0.75 \\
\hline TK1 & I have the technical skills to use computers effectively. & 0.78 \\
\hline TK2 & I can learn technology easily. & 0.78 \\
\hline TK3 & I know how to solve my own technical problems when using technology. & 0.76 \\
\hline TK4 & I keep up with important new technologies. & 0.79 \\
\hline TK5 & I am able to create web pages. & 0.57 \\
\hline TK6 & I am able to use social media (e.g., blogs, wikis, Facebook). & 0.74 \\
\hline TK7 & $\begin{array}{l}\text { I am able to use web-based communication tools (IM, MSN Messenger, } \\
\text { ICQ, Skype, etc.). }\end{array}$ & 0.72 \\
\hline TPTCK1 & $\begin{array}{l}\text { I am able to facilitate my students to use technology to find more } \\
\text { information on their own. }\end{array}$ & 0.62 \\
\hline TPTCK2 & $\begin{array}{l}\text { I am able to facilitate my students to use technology to plan and monitor } \\
\text { their own learning. }\end{array}$ & 0.70 \\
\hline
\end{tabular}


Table 1 (continued)

\begin{tabular}{|c|c|c|}
\hline Item & Measure & $\begin{array}{l}\text { Factor } \\
\text { loading }\end{array}$ \\
\hline TPTCK3 & $\begin{array}{l}\text { I am able to facilitate my students to use technology to construct different } \\
\text { forms of knowledge representation. }\end{array}$ & 0.75 \\
\hline ТРТCK4 & $\begin{array}{l}\text { I am able to facilitate my students to collaborate with each other using } \\
\text { technology. }\end{array}$ & 0.78 \\
\hline TPТCK5 & I can use the software that is created specifically for my teaching subject. & 0.78 \\
\hline ТРТСК6 & $\begin{array}{l}\text { I know about the technologies that I have to use for the content of my } \\
\text { teaching subject. }\end{array}$ & 0.81 \\
\hline TPТCK7 & $\begin{array}{l}\text { I can use appropriate technologies (e.g., multimedia resources, simulation) to } \\
\text { represent the content of my teaching subject. }\end{array}$ & 0.78 \\
\hline TPТCK8 & $\begin{array}{l}\text { I can use specialized software to perform inquiries about my teaching } \\
\text { subject. }\end{array}$ & 0.71 \\
\hline TPCK1 & $\begin{array}{l}\text { I can select technologies to use in my classroom that enhance what I teach, } \\
\text { how I teach and what students learn. }\end{array}$ & 0.65 \\
\hline TPCK2 & $\begin{array}{l}\text { I can use strategies that combine content, technologies and teaching } \\
\text { approaches that I learned about in my coursework in my classroom. }\end{array}$ & 0.71 \\
\hline TPCK3 & $\begin{array}{l}\text { I can provide leadership in helping others to coordinate the use of content, } \\
\text { technologies and teaching approaches at my school and/or district. }\end{array}$ & 0.77 \\
\hline TPCK4 & $\begin{array}{l}\text { I can design lessons that appropriately integrate content, technology and } \\
\text { pedagogy for student-centred learning. }\end{array}$ & 0.73 \\
\hline
\end{tabular}

\section{Preschool teachers' responses on the scales}

The preschool teachers' mean scores on the six scales of the TPACK survey are listed in Table 2. It can be seen that the preschool teachers' mean scores for the factors were all over 5 points on a seven-point scale, except for the TK and TPTCK scales (4.99 and 4.88) (Table 2). Of the six scales of the TPACK survey, the preschool teachers attained the highest scores on the 'PK' scale (an average of 5.63 per item) and then the PCK scale (an average of 5.48 per item) based on the 1-7 Likert measurement. Although they scored relatively lower on the TK and TPTCK scales (an average of 4.88 and 4.99 per item) compared to the other scales, the average scores remained higher than the mean of the seven-point Likert scale (i.e., 4). This result implies that most of the preschool teachers tended to show the highest agreement for their perceived capability of teaching methods $(\mathrm{PK})$ and how to use proper instruction to teach the intended content knowledge (PCK). However, their relatively lower scores for TK and TPTCK still imply that a number of the preschool teachers exhibited a certain degree of doubt or concern about their sufficient level of technological knowledge in using technology to conduct instructional activities and to teach the subject matter.

Table 2

Preschool teachers' descriptive data on each scale of the TPACK

\begin{tabular}{lccc}
\hline Factor & Mean (per item) & $S D$ & Range \\
\hline CK & 5.30 & 0.94 & $2.0-7.0$ \\
PK & 5.63 & 0.78 & $3.2-7.0$ \\
PCK & 5.48 & 0.87 & $2.5-7.0$ \\
TK & 4.99 & 1.18 & $1.0-7.0$ \\
TPTCK & 4.88 & 1.13 & $1.0-7.0$ \\
TPCK & 5.24 & 1.18 & $1.0-7.0$ \\
\hline
\end{tabular}




\section{Correlations between the preschool teachers' age/years of service and TPACK}

Pearson's correlation was used to examine the relationships between the preschool teachers' age and years of service and the TPACK scales. The results are shown in Table 3. The correlation analysis indicated that the preschool teachers' age plays an important role in all technology related knowledge factors, such as the TK, TPTCK and TPCK scales of the TPACK survey, revealing negative relationships between age and these scales. These results indicate that senior preschool teachers tend to perceive themselves as having less technology-related knowledge within the TPACK framework.

The findings of the correlations of the preschool teachers' years of service and TPACK survey were almost the same as that pertaining to age, except for the TPTCK scale, which is not significantly correlated. The correlation results suggest that those preschool teachers with longer years of teaching experience perceived that they are less knowledgeable about technology (TK) and ICT integration (TPCK).

Table 3

The correlations between the subscales of the TPACK survey and preschool teachers' age or years of service

\begin{tabular}{lcccccc}
\hline & CK & PK & PCK & TK & TPTCK & TPCK \\
\hline Age & -0.01 & 0.08 & 0.07 & $-0.30^{* * *}$ & $-0.14^{* *}$ & $-0.16^{* *}$ \\
Years of service & -0.06 & 0.06 & 0.06 & $-0.21 * * *$ & -0.07 & $-0.13^{*}$ \\
\hline
\end{tabular}

Note. ${ }^{*} p<.05 ; * * p<.01 ; * * * \mathrm{p}<.001$

\section{The comparisons of preschool teachers' responses to the TPACK survey by their education qualifications}

This study also examined the role of the preschool teachers' education qualifications in their responses to the TPACK survey. In this study, the preschool teachers' self-reported education qualifications were grouped into three groups (senior high school, junior college and university). A series of $F$-tests were further used to compare these three groups' responses regarding their perceived TPACK knowledge. It was found that in the TK scale, the scores of the preschool teachers with university degrees were significantly higher than those with senior high school or junior college qualifications. In addition, the preschool teachers with university degrees scored significantly higher than those with senior high school qualifications for the factor of TPCK. These findings indicate that those preschool teachers with relatively higher education qualifications (in this study, a university degree) tended to have better perceived competence in the capacities of applying technology and of ICT integration in their instructional environment for teaching subject matter to children.

Table 4

Comparisons of preschool teachers' scores on the scales of the TPACK among three groups of preschool teachers' education qualifications

\begin{tabular}{|c|c|c|c|c|c|}
\hline Degree & $\begin{array}{c}\text { (1) } \text { Senior high } \\
\text { school }(n=70) \\
(\text { Mean, } S D)\end{array}$ & $\begin{array}{c}\text { (2) Junior college } \\
(n=129) \\
(\text { Mean, } S D)\end{array}$ & $\begin{array}{c}\text { (3) University } \\
(n=167) \\
\text { (Mean, } S D)\end{array}$ & $\begin{array}{l}\text { F (ANOVA) } \\
\text { Scheffe Test }\end{array}$ & \\
\hline CK & $(5.17,0.97)$ & $(5.29,0.83)$ & $(5.36,1.01)$ & 1.06 & \\
\hline PK & $(5.55,0.83)$ & $(5.70,0.73)$ & $(5.60,0.79)$ & 1.08 & \\
\hline PCK & $(5.48,0.85)$ & $(5.44,0.82)$ & $(5.51,0.92)$ & 0.24 & \\
\hline TK & $(4.50,1.28)$ & $(4.84,1.09)$ & $(5.29,1.12)$ & $12.58 * * *$ & $\begin{array}{l}(3)>(1) \\
(3)>(2)\end{array}$ \\
\hline TPТCК & $(4.62,1.27)$ & $(4.85,1.04)$ & $(5.00,1.11)$ & 2.78 & \\
\hline TPCK & $(4.86,1.28)$ & $(5.23,1.21)$ & $(5.41,1.07)$ & $5.71 * *$ & $(3)>(1)$ \\
\hline
\end{tabular}




\section{Discussion}

This study explored a group of Taiwanese preschool teachers' technological pedagogical content knowledge. A TPACK survey was applied to measure their technological pedagogical content knowledge. Through the exploratory factor analysis, the results reveal that the TPACK survey largely concurs with the findings of previous studies using a similar questionnaire (Chai, Koh, \& Tsai, 2011), except for the merging of TPK and TCK. The findings also indicate that the survey is sufficiently reliable for exploring the preschool teachers' technological pedagogical content knowledge. The preschool teacher educators could adapt this survey to investigate preschool teachers' technological pedagogical content knowledge in subsequent studies of other countries or educational contexts.

With regards to the combined factor TPTCK, the merging of the TPK and TCK factors indicated that the teachers were unable to distinguish the current set of items. The merging of factors is not uncommon in survey studies for TPACK (e.g., Archamabault \& Barnett, 2010; Koh, Chai, \& Tsai, 2010; Lee \& Tsai, 2010). The TCK items in this study were formulated for subject specific representation assisted by technology. Examples of TCK items are "I can use appropriate technologies (e.g., multimedia resources, simulation) to represent the content of my teaching subject" and "I can use specialized software to perform inquiries about my teaching subject." These TCK items load as a unique factor for the pre-service teachers in Chai, Koh, and Tsai's (2011) study, but the participants in that study were all university graduates with relevant specialized subject knowledge, who were attending pre-service training. The participants in this study are practicing teachers of children below 7 years old, and the content they deal with is relatively simple and general. In addition, more than half of them do not have a university degree. Such contextual differences may explain the merging of TPK and TCK.

Cox and Graham (2009) pointed out that TCK items should not be associated with the pedagogical factors. In addition, TCK refers to technological representation of specific content knowledge. Cox and Graham provide an example of how a university researcher used MATLAB (specialized 3D modelling software) to represent the composition of glacier numerical data obtained through ice core drills. The researcher needed to perform the task of creating technological representations as part of her research work, regardless of whether or not she would use the representations for teaching. In the context of early childhood education, the teachers rarely, if ever, have to perform such a complex task. Without such a need, it is understandable that preschool teachers may not have a clear notion of what TCK is. Furthermore, bearing in mind that we are discussing content knowledge without consideration of teaching, the degree of specialized forms of knowledge that need to be uniquely represented with the help of technology may in fact be non-existent for preschool teachers. This again does not encourage the preschool teachers to develop TCK. As such, TCK may not be a meaningful factor to survey in the preschool context. In other words, one may question the necessity of surveying all 7 factors of the TPACK framework in this particular context. Alternatively, future research should interview preschool teachers to understand the specific form of technologically represented content knowledge they draw upon, and reformulate the items for TCK accordingly. We propose that in the preschool context, the nature of TCK should be more geared toward web-based animated resources for specific topics rather than technological representation of advanced content knowledge.

An increasing number of studies have highlighted that technology is playing a critical role in improving early childhood education pedagogical content for preschool teachers (Al-Senaidi, Lin, \& Poirot, 2009; Karasavvidis, 2009; Panagiotakou \& Pange, 2010). There is also an absolute need to train preschool teachers to become familiar with new teaching environments by means of using technologies, and to help them to gain knowledge about using technologies while teaching (Yurt \& Cevher-Kalburan, 2011; Gialamas \& Nikolopoulou, 2010). This study shows that the preschool teachers are reportedly less competent in technology-related factors of the TPACK framework. It thus lends support to the call to reform preschool teacher education. In addition, this study suggests that the TPACK survey constitutes a viable framework for analysing and understanding preschool teachers' technological pedagogical content knowledge. The current survey can be improved upon to serve as a needs assessment and evaluation tool for preschool teacher educators.

In addition, the correlation results of this study indicate that both the preschool teachers' age and years of service were important factors in their technology-related TPACK knowledge. The preschool teachers' age was negatively related to the TK, TPTCK and TPCK scales. Similarly, the preschool teachers' years 
of working experience were negatively related to the TK and TPCK scales of the TPACK survey, implying that preschool teachers with more years of teaching tend to have less technological knowledge and ICT integration. That is, the senior preschool teachers (i.e., those who are older or who have more years of teaching) may perceive moderate barriers to applying technology in learning environments. Previous studies have also concluded that technology-related self-efficacy (such as internet self-efficacy) may be negatively correlated with years of service or age (Liang \& Wu, 2010; Liang, Wu, \& Tsai, 2011). Given that teacher professional development programs designed according to the TPACK framework have generated positive outcomes in raising teachers' TPACK related competencies and self-efficacy among teachers for the mainstream (Angeli \& Valnides, 2005; Chai, Koh, \& Tsai, 2010; Mishra \& Khoeler, 2006; Tsai, Chuang, Liang, \& Tsai, 2011), preschool teacher educators can propose similar programs to help the more senior teachers. We anticipate that future research in educating preschool teachers employing the TPACK framework would be generally successful given the research to date.

This study also examined the role of preschool teachers' education qualifications in the TPACK survey. In the TK and TPCK scales, in general, the scores of the university graduates were significantly higher than those with lower qualifications (in this study, senior high school or a junior college degree). The findings suggest a linkage between the in-service preschool teachers' education qualifications and the readiness of their technological pedagogical content knowledge. That is, the preschool teachers with higher qualifications tended to perceive having more sophisticated knowledge of using technology and ICT integrations in their classrooms.

According to the results of this study, in-service preschool teachers' education qualifications seem to be a critical factor that could help them enhance their technological pedagogical content knowledge, especially for the senior preschool teachers who are lacking in or are unfamiliar with instructional technologies. Senior preschool teachers are encouraged to participate in continuing professional learning. Nowadays, web-based professional development programs are gradually growing in popularity. In such programs, the teachers can learn at their own pace. This could be a suitable way for the senior preschool teachers to gain more knowledge of the technologies needed in their teaching environment and how to better use technology to enhance their instruction.

This study validated a survey for the purpose of assessing preschool teachers' TPACK competencies. The six factor structure obtained indicates that the survey is a valid and reliable tool that can be used to profile preschool teachers' TPACK knowledge. Future research could build on this current survey to obtain all seven factors so as to provide a more comprehensive survey of TPACK among preschool teachers. It is suggested that future research should conduct in-depth interviews for a certain number of preschool teachers to develop appropriate TPACK survey items particularly for the preschool setting. The new survey items could then be used in pilot studies with special cohorts of preschool teachers (such as the teachers with extensive technology integration with instruction versus those with little technology integration), and these studies could provide recommendations for modification of the survey for future use. In addition, the findings of this survey also indicate that older teachers need continuous professional development activities to help them grow with the advancements of technology. We suggest that future professional development programs employ the TPACK framework and study the effects of such programs within the context of preschool teacher education.

\section{Acknowledgements}

Funding of this research work was supported by the National Science Council, Taiwan, under grant number NSC 99-2511-S-011-008-MY3 and NSC 99-2511-S-011-005-MY3. 


\section{References}

Al-Senaidi, S., Lin, L., \& Poirot, J. (2009). Barriers to adopting technology for teaching and learning in Oman. Computers \& Education, 53(3), 575-590. Retrieved from http://www.sciencedirect.com/science/article/pii/S0360131509000827

Angeli, C., \& Valanides, N. (2005). Preservice elementary teachers as information and communication technology designers: an instructional systems design model based on an expanded view of pedagogical content knowledge. Journal of Computer Assisted Learning, 21(4), 292-302. Retrieved from

http://onlinelibrary.wiley.com/doi/10.1111/j.1365-2729.2005.00135.x/abstract;jsessionid=00F8C041D 5754E21AD39B43C8C518E34.d04t02?deniedAccessCustomisedMessage $=$ \&userIsAuthenticated=fal se

Angeli, C., \& Valanides N. (2009). Epistemological and methodological issues for the conceptualization, development, and assessment of ICT-TPCK: Advances in technological pedagogical content knowledge (TPCK). Computers \& Education, 52(1), 154-168. Retrieved from http://www.sciencedirect.com/science/article/pii/S0360131508001085

Archambault, L. M., \& Barnett, J. H. (2010). Revisiting technological pedagogical content knowledge: Exploring the TPACK framework. Computers \& Education, 55(4), 1656-1662. Retrieved from http://www.sciencedirect.com/science/article/pii/S0360131510002010

Chai, C. S., Koh, J. H. L., \& Tsai, C. C. (2010). Facilitating preservice teachers' development of technological, pedagogical, and content knowledge (TPACK). Journal of Educational Technology \& Society, 13(4), 63-73. Retrieved from http://www.ifets.info/journals/13_4/ets_13_4.pdf\#page=68

Chai, C. S., Koh, J. H. L., \& Tsai, C. C. (2011). Exploring the factor structure of the constructs of technological, pedagogical, content knowledge (TPACK). The Asia-Pacific Education Researcher, 20(3), 607-615. Retrieved from http://ejournals.ph/index.php?journal=TAPER\&page=article\&op=viewFile \&path $\% 5 B \% 5 \mathrm{D}=3800 \&$ pa th $\% 5 \mathrm{~B} \% 5 \mathrm{D}=4029$

Chai, C. S., Koh, J. H. L., \& Tsai, C.-C. (2013). A review of technological pedagogical content knowledge. Journal of Educational Technology \& Society, 16(2), 31-51. Retrieved from http://www.ifets.info/journals/16_2/4.pdf

Chai, C. S., Koh, J. H. L., Tsai, C. C., \& Tan, L. (2011). Modeling primary school pre-service teachers' technological pedagogical content knowledge (TPACK) for meaningful learning with information and communication technology (ICT). Computers \& Education, 57(1), 1184-1193. Retrieved from http://www.sciencedirect.com/science/article/pii/S0360131511000157

Collins, A., \& Halverson, R. (2010). The second educational revolution: Rethinking education in the age of technology. Journal of Computer Assisted Learning, 26(1), 18-27. Retrieved from http://onlinelibrary.wiley.com/doi/10.1111/j.1365-2729.2009.00339.x/abstract?deniedAccessCustomis edMessage $=\&$ userIsAuthenticated $=$ false

Cox, S., \& Graham, C. R. (2009). Diagramming TPACK in practice: Using an elaborated model of the TPACK framework to analyze and depict teacher knowledge. TechTrends: Linking Research \& Practice to Improve Learning, 53(5), 60-69. Retrieved from http://www.springerlink.com/content/p07mkkk777314144/

Gao, P., Chee, T. S., Wang, L. L., Wong, A., \& Choy, D. (2011). Self reflection and preservice teachers' technological pedagogical knowledge: Promoting earlier adoption of student-centred pedagogies. Australasian Journal of Educational Technology, 27(6), 997-1013. Retrieved from http://www.ascilite.org.au/ajet/ajet27/gao.pdf 
Gialamas, V., \& Nikolopoulou, K. (2010). In-service and pre-service early childhood teachers' views and intentions about ICT use in early childhood setting: a comparative study. Computers \& Education, 55(1), 333-341. Retrieved from http://www.sciencedirect.com/science/article/pii/S0360131510000333

Graham, C. R. (2011). Theoretical considerations for understanding technological pedagogical content knowledge (TPACK). Computers \& Education, 57(3), 1953-1960. Retrieved from http://www.sciencedirect.com/science/article/pii/S0360131511000911

Grimley, M., \& Allan, M. (2010). Towards a pre-teen typology of digital media. Australasian Journal of Educational Technology, 26(5), 571-584. Retrieved from http://www.ascilite.org.au/ajet/ajet26/grimley.pdf

Haugland, S. W. (1992). Effects of computer software on early childhood children's developmental gains. Journal of Computing in Childhood Education, 3(1), 15-30.

Hsu, C. Y., Tsai, C. C., \& Liang, J. C. (2011). Facilitating preschoolers' scientific knowledge construction via computer games regarding light and shadow: The effect of the prediction-observation-explanation (POE) strategy. Journal of Science Education and Technology, 20(5), 482-493. Retrieved from http://www.springerlink.com/content/d211678263528t85/

Karasavvidis, I. (2009). Activity theory as a conceptual framework for understanding teacher approaches to information and communication technologies. Computers \& Education, 53(2), 436-444. Retrieved from http://www.sciencedirect.com/science/article/pii/S0360131509000700

Koehler, M. J., \& Mishra, P. (2009). What is technological pedagogical content knowledge? Contemporary Issues in Technology and Teacher Education, 9(1), 60-70. Retrieved from http://www.citejournal.org/vol9/iss1/general/article1.cfm

Koh, J. H. L., Chai, C. S., \& Tsai, C. C. (2010). Examining the technological pedagogical content knowledge of Singapore pre-service teachers with a large-scale survey. Journal of Computer Assisted Learning, 26(6), 563-573. Retrieved from http://onlinelibrary.wiley.com/doi/10.1111/j.1365-2729.2010.00372.x/abstract?deniedAccessCustomis edMessage $=\&$ userIsAuthenticated $=$ false

Lee, M. H., \& Tsai, C. C. (2010). Exploring teachers' perceived self efficacy and technological pedagogical content knowledge with respect to educational use of the world wide web. Instructional Science, 38(1), 1-21. Retrieved from http://www.springerlink.com/content/d510480505435104/

Li, H. (2006). Integrating information and communication technologies into early childhood curriculum: Chinese principals' views of the challenges and opportunities. Early Education \& Development, 17(3), 467-487. Retrieved from http://www.tandfonline.com/doi/abs/10.1207/s15566935eed1703_7

Liang, J. C., \& Wu, S. H. (2010). Nurses' motivations for web-based continuing learning and the role of internet self-efficacy. Innovations in Education and Teaching International, 47(1), 25-37. Retrieved from http://www.tandfonline.com/doi/abs/10.1080/14703290903525820

Liang, J. C., Wu, S. H., \& Tsai, C. C. (2011). Nurses' internet self-efficacy and attitudes toward web-based continuing learning. Nurse Education Today, 31(8), 768-773. Retrieved from http://www.sciencedirect.com/science/article/pii/S0260691710002479

Lim, C. P., \& Chai, C. S. (2008). Teachers' pedagogical beliefs and their planning and conduct of computer-mediated classroom lessons. British Journal of Educational Technology, 39(5), 807-828. Retrieved from http://onlinelibrary.wiley.com/doi/10.1111/j.1467-8535.2007.00774.x/abstract?deniedAccessCustomis edMessage $=$ \&userIsAuthenticated $=$ false 
Linuesa, M. C., Orellana, E. R., Baz, B. O., \& Dominguez, J. M. (2011). Digital resources in classroom practice: action plans of early childhood teachers. Revista De Education, 356, 211-232. Retrieved from http://www.revistaeducacion.educacion.es/re356/re356_09.pdf

Liu, S. H. (2011). Factors related to pedagogical beliefs of teachers and technology integration. Computers \& Education, 56(4), 1012-1022. Retrieved from http://0-www.sciencedirect.com.millennium.lib.ntust.edu.tw/science/article/pii/S0360131510003507

Mason, R. B. (2011). Student engagement with, and participation in, an e-forum. Educational Technology \& Society, 14(2), 258-268. Retrieved from http://www.ifets.info/journals/14_2/22.pdf

Mishra, P., \& Koehler M. J. (2006). Technological pedagogical content knowledge: a framework for teacher knowledge. Teachers College Record, 108(6), 1017-1054. Retrieved from https://tcrecord.org/Content.asp?ContentID=12516

O'Mara, J., \& Laidlaw, L. (2011). Living in the iworld: two literacy researchers reflect on the changing texts and literacy practices of childhood. English Teaching-Practice and Critique, 10(4), 149-159. Retrieved from http://edlinked.soe.waikato.ac.nz/research/files/etpc/files/2011v10n4nar2.pdf

Önkol, F. L., Zembat, R., \& Balat, G. U. (2011). Computer use attitudes, knowledge and skills, habits and methods of preschool teachers. Procedia Computer Science, 3, 343-351. Retrieved from http://www.sciencedirect.com/science/article/pii/S1877050910004333

Panagiotakou, C., \& Pange, J. (2010). The use of ICT in preschool music education. Procedia Social and Behavioral Sciences, 2(2), 3055-3059. Retrieved from http://www.sciencedirect.com/science/article/pii/S1877042810005045

Perry, B., Tracey, D., \& Howard, P. (1999). Head mathematics teachers' beliefs about the learning and teaching of mathematics. Mathematics Education Research Journal, 11(1), 39-53. Retrieved from http://www.springerlink.com/content/j68857722ntq82p4/

Polly, D., Mims, C., Shepherd, C. E., \& Inan, F. (2010). Evidence of impact: transforming teacher education with preparing tomorrow's teachers to teach with technology (PT3) grants. Teaching and Teacher Education, 26, 863-870. Retrieved from http://0-www.sciencedirect.com.millennium.lib.ntust.edu.tw/science/article/pii/S0742051X09002224

Schmidt, A. D., Baran, E., Thompson, A. D., Mishra, P., Koehler, M. J., \& Shin, T. S. (2009). Technological pedagogical content knowledge (TPACK): The development and validation of an assessment instrument for preservice teachers. Journal of Research on Technology in Education, 42(2), 123-149. Retrieved from http://learnonline.canberra.edu.au/pluginfile.php/491591/mod_page/content/1/TPACK_UC/pdf/tpack $4 \_$preservice $2 . p d f$

Shulman, L. S. (1986). Those who understand: Knowledge growth in teaching. Educational Researcher, 15(2), 4-14. Retrieved from http://www.jstor.org/discover/10.2307/1175860?uid=3739216\&uid=2\&uid=4\&sid=21100980850933

Tee, M. Y., \& Lee, S. S. (2011). From socialization to internalisation: Cultivating technological pedagogical content knowledge through problem-based learning. Australasian Journal of Educational Technology, 27(1), 89-104. Retrieved from http://www.ascilite.org.au/ajet/ajet27/tee.pdf

Thole, W. (2010). The pedagogical staff in day care - professionalism and professionalization in a pedagogical field of work. Zeitschrift fur Padagogik, 56(2), 206-222.

Tsai, C. C., Chuang, S. C., Liang, J. C., \& Tsai, M. J. (2011). Self-efficacy in Internet-based learning environments: A literature review. Educational Technology \& Society, 14(4), 222-240. Retrieved from http://www.ifets.info/journals/14_4/19.pdf 
Valtonen, T., Kukkonen, J., Wulff, A. (2006). High school teachers' course designs and their professional knowledge of online teaching. Informatics in Education, 5(2), 301-316. Retrieved from http://www.mii.lt/informatics_in_education/pdf/INFE083.pdf

Wang, X. C., \& Hoot, J. L. (2006). Information and communication technology in early childhood education. Early Education \& Development, 17(3), 317-322. Retrieved from http://www.tandfonline.com/doi/abs/10.1207/s15566935eed1703_1

Wu, H. K., Lee, S, W. Y., Chang, H. Y., \& Liang, J. C. (2013) Current status, opportunities and challenges of augmented reality in education. Computers \& Education, 62, 41-49. Retrieved from http://0-www.sciencedirect.com.millennium.lib.ntust.edu.tw/science/article/pii/S0360131512002527

Wu, W. H., Chen, W. F., Wang, T. L., \& Su, C. H. (2008). Developing and evaluating a game-based software engineering educational system. International Journal of Engineering Education, 24(4), 681-688. Retrieved from http://www.ingentaconnect.com/content/intjee/ijee/2008/00000024/00000004/art00006? crawler=true

Yurt, Ö., \& Cevher-Kalburan, N. (2011). Early childhood teachers' thoughts and practices about the use of computers in early childhood education. Procedia Computer Science, 3, 1562-1570. Retrieved from http://www.sciencedirect.com/science/article/pii/S1877050911000512

Corresponding author: Jyh-Chong Liang, aljc@mail.ntust.edu.tw

Australasian Journal of Educational Technology (C) 2013.

Please cite as: Liang, J.-C., Chai, C. S., Koh, J. H. L., Yang, C.-J., \& Tsai, C.-C. (2013). Surveying in-service preschool teachers' technological pedagogical content knowledge. Australasian Journal of Educational Technology, 29(4), 581-594. 